\title{
Drug prices in Latin American countries: the case of rheumatoid arthritis Biosimilars
}

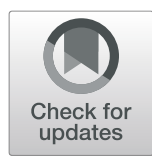

Gabriela Bittencourt Gonzalez Mosegui ${ }^{i^{*}}$ (D), Fernando Antõnanzas², Cid Manso de Mello Vianna ${ }^{3}$ and Paula Rojas ${ }^{4}$

\begin{abstract}
Background: The objective of this paper is to analyze the prices of biological drugs in the treatment of Rheumatoid Arthritis (RA) in three Latin American countries (Brazil, Colombia and Mexico), as well as in Spain and the United States of America (US), from the point of market entry of biosimilars.

Methods: We analyzed products authorized for commercialization in the last 20 years, in Brazil, Colombia, and Mexico, comparing them to the United States of America (USA) and Spain. For this analysis, we sought the prices and registries of drugs marketed between 1999 and October 1, 2019, in the regulatory agencies' databases. The pricing between countries was based on purchasing power parity (PPP).

Results: The US authorized the commercialization of 13 distinct biologicals and four biosimilars in the period. Spain and Brazil marketed 14 biopharmaceuticals for RA, ten original, four biosimilars. Colombia and Mexico have authorized three biosimilars in addition to the ten biological ones. For biological drug prices, the US is the most expensive country. Spain's price behavior seems intermediate when compared to the three LA countries. Brazil has the highest LA prices, followed by Mexico and Colombia, which has the lowest prices. Spain has the lowest values in PPP, compared to LA countries, while the US has the highest prices.

Conclusion: The economic effort that LA countries make to access these medicines is much higher than the US and Spain. The use of the PPP ensured a better understanding of the actual access to these inputs in the countries analyzed.
\end{abstract}

Keywords: Biological products, Antirheumatic agents, Access to essential medicines and health technologies, Products registration, Drug Price

\section{Introduction}

Rheumatoid arthritis (RA) is a chronic inflammatory autoimmune disease that affects 0.3 to $1.0 \%$ of the world population. This prevalence seems to be lower in emerging countries, given the differences in age distribution among population groups, difficulty in accessing the health system, lack of diagnosis and lack of studies [1].

Biological agents used to treat moderate or severe active disease reduce inflammation and prevent joint damage [2]. These are innovative products made from living

\footnotetext{
*Correspondence: gabrielamosegui@uol.com.br

'Department of Health and Society, Community Health Institute, Fluminense Federal University, Rua: Marquês do Paraná, 303, $3^{\circ}$ floor, annex building,

Niterói, RJ CEP: 24033-900, Brazil

Full list of author information is available at the end of the article
}

cells whose development is longer and more costly than that of traditional products. The economic risks involved in this process are high. There is no difference in obtaining a biosimilar drug, where companies assume the same strategic level as those who hold the patents or creators of the original biopharmaceutical [3]. Biosimilars are not generic drugs and may differ from reference products in manufacturing, composition and formulation [4].

In the US market, few biosimilars are available as a result of the high cost of approval and price competition from manufacturers of reference drugs [5]. The European Medicines Agency (EMA) has authorized the first biosimilar in over than10 years, and since then, there has been an intense debate about access, penetration with regard to originals and the prescription of these

(c) The Author(s). 2021 Open Access This article is licensed under a Creative Commons Attribution 4.0 International License, which permits use, sharing, adaptation, distribution and reproduction in any medium or format, as long as you give appropriate credit to the original author(s) and the source, provide a link to the Creative Commons licence, and indicate if changes were made. The images or other third party material in this article are included in the article's Creative Commons licence, unless indicated otherwise in a credit line to the material. If material is not included in the article's Creative Commons licence and your intended use is not permitted by statutory regulation or exceeds the permitted use, you will need to obtain permission directly from the copyright holder. To view a copy of this licence, visit http://creativecommons.org/licenses/by/4.0/. 
products in European Union (EU) countries. There are some factors that can influence the entry of biosimilars into the markets of different countries, ranging from the product itself, the therapeutic area to which the product is directed, the sanitary policy adopted, the price and therefore the access, and finally the prescriptive standards [6].

These supplies are among the top-selling drugs in the world market. In Brazil, in 2017, the revenues of companies that marketed biopharmaceuticals was R\$ 15,409 , 519,216 or US $\$ 491,707,322$ [7]. Four of the twenty substances with the highest revenues this year in the Brazilian market were biological, with three of them (adalimumab, infliximab, and etanercept) used for RA [7]. All of these therapeutic options already have biosimilars on the market [8-10]. In 2013, biosimilars accounted for approximately $25 \%$ of the total biological sales, the patents of which having expired in the EU. In 2015, the biosimilar market amounted to US\$ 490 million in the EU-5, Germany, Spain, France, Italy and the United Kingdom [6].

According to Zozoya and González [11] some studies have tried to estimate the economy magnitude produced with biosimilar introduction. In Spain, this saving was between 300 and 2800 million euros between 2007 and 2020. In Latin America, the regulation and penetration of these drugs varies considerably [12], and most of the available studies focus on the normative issue, not on prices] [4, 12-15].

The importance of biosimilars in public health is related to the costs of the original medicines and the demographic and epidemiological profiles of the population. Their adoption can lead to considerable cost savings [15]. It is crucial to the political debate to have concrete data on how the biosimilar market is evolving and how it will behave in the future, given the high degree of innovation in the sector and the speed of incorporation of new technologies demanded by society and health systems. The objective of this paper is to analyze the prices of biological drugs in the treatment of RA in three LA countries, namely, Brazil, Colombia and Mexico, as well as in Spain and the United States of America (US), from the point of market entry of biosimilars.

\section{Methods}

The records and prices of biological products of the antirheumatic class used in the treatment of RA, approved from 1998 in Brazil, Colombia and Mexico, were analyzed. An initial list of medicines for the treatment of RA released annually in the US market by the Food and Drug Administration (FDA) has been created [9]. Registration information on these drugs has been taken from Brazilian drug regulatory agencies - Agência Nacional de
Vigilância Sanitária (Anvisa), from Colombia - Instituto Nacional de Vigilância de Medicamentos y Alimentos (Invima), from Spain (Consejo General de Colegios Oficiales de Farmacéuticos) and from Mexico - Comisión Federal para la Protección contra Riesgos Sanitarios (Cofepris) [16-19]. RA treatment guides from each of these countries were reviewed and consulted in pursuit of other therapeutic possibilities that had not been captured to complement the registration data [2].

From the product lists launched between 1998 and 2019, 14 authorized in Spain and Brazil, 16 in the US, and 13 in Mexico and Colombia, a sample of 10 antirheumatic biological drugs common to all these countries was defined for the treatment of RA. These were listed by authorization year, pharmaceutical form(s), and similar packaging. Biosimilars authorized in this period were also included. For these inputs, the date taken corresponded to when the first manufacturer registered the product by searching data information in Anvisa, Cofepris, Consejo General of Official Colleges of Pharmaceuticals and Invima, by year of publication and by consulting the records [16-19]. The year of marketing authorization publication guided price monitoring. The drug associations were excluded. The unit of analysis of the study was the product, considering the same concentrations and packaging.

Price research was carried out on the official bases of each of these countries, except for the US. The values identified were the retail reference values for the year 2019. In Brazil, the prices on the Anvisa website [20] were consulted. The standard set for Brazil was the maximum consumer price (MCP), which refers to $18 \%$ of the tax on the circulation of goods and services. In the US, market prices were captured from Drugs.com [21], and in Spain, from Consejo General de Colegios Oficiales de Farmacéuticos [19]. Colombian prices were obtained from reference price listings from 2019 for the month/ base September in the Digital Institutional Repository of the Ministry of Health [22]. In Mexico, reference prices for patented drugs were obtained from an official price list [23]. Complementary consultation was made at the Government-recommended site for 2019 only [24].

For products with different quantities of pharmaceutical units per package, for the same pharmaceutical form and concentration, the price of the package with the largest quantity or cheapest presentation was taken. Only two drug samples differed in presentation and concentration, and both were reduced to the smallest unit of presentation for comparison.

All prices were converted to US dollars using the Central Bank of Brazil exchange rates [25]; the purchasing power or purchasing power parity (PPP) was used as another price comparator. PPP conversion factor is a currency converter and spatial price deflator that controls 
for price level differences between countries. PPP values for 2019 were used, the latest available from the World Bank [26, 27].

This study did not require institutional review board approval or informed consent, as it was based on public data and did not involve patient records.

\section{Results}

The immunobiological drugs and biosimilar drugs analyzed, which are simultaneously registered and appear in official lists as well as in the clinical protocols of the 3 LA countries, are listed in the following table.

The registered year of publication guided the price monitoring developments in subsequent years. In the US, the FDA registered 13 distinct biologicals in the period and 4 biosimilars. Spain and Brazil recorded the 14 selected RA drugs in the period: 10 originals and 4 biosimilars. Colombia and Mexico registered 3 biosimilars in addition to 10 biologicals $[9,18,20,28]$. Biosimilars approved for commercialization include adalimumab, etanercept, infliximab and rituximab. The
FDA approved all these biosimilars, but only infliximab is marketed. Adalimumab is authorized only in Spain, while etanercept and infliximab are approved in the three LA countries and in Spain. Rituximab is not in Invima, the Colombian registration system.

There is no average difference between the release time in the US and that in other countries that deserves consideration as an indication of the greater "availability" of these inputs in one country or another. Marketing authorizations for biopharmaceuticals and biosimilars in the US are from 2002. Although Spain, Brazil and Colombia have approved biological agents for RA since the 1990s, we concentrate on those from 2014, 2009 and 2015, respectively; additionally, Mexico has approved them since 2013. For biosimilars, Spain has adopted them since 2013, Brazil since 2014, Colombia since 2006 and Mexico since 1999.

Table 1 shows the prices in US dollars and PPP of medicines per package in the analyzed markets.

The blank cells in Table 2 represent data not found in the queried databases. Regarding the prices of biological medicines used for RA, the US is the most expensive

Table 1 Prices comparison of RA biological agents registered between 1998 and 2019 in Brazil, Colombia, Spain, United States (US) and Mexico, in US dollars (US\$) per presentation and PPP. Source: [19-27]

\begin{tabular}{|c|c|c|c|c|c|c|c|c|c|c|}
\hline Drug & Dosage forms (DF) & $\begin{array}{l}\text { US } \\
\text { (US\$/ } \\
\text { DF) }\end{array}$ & $\begin{array}{l}\text { Spain } \\
\text { (US\$/ } \\
\text { DF) }\end{array}$ & $\begin{array}{l}\text { PPP } \\
\text { Spain }\end{array}$ & $\begin{array}{l}\text { Brazil } \\
\text { (US\$/ } \\
\text { DF) }\end{array}$ & $\begin{array}{l}\text { PPP } \\
\text { Brazil }\end{array}$ & $\begin{array}{l}\text { Colombia } \\
\text { (US\$/DF) }\end{array}$ & $\begin{array}{l}\text { PPP } \\
\text { Colombia }\end{array}$ & $\begin{array}{l}\text { Mexico } \\
\text { (US\$/DF) }\end{array}$ & $\begin{array}{l}\text { PPP } \\
\text { Mexico }\end{array}$ \\
\hline Abatacept & 250 mg, injection powder & 1167,3 & 447,2 & 636,5 & 450,2 & 812,5 & 324,4 & 823,8 & 431,8 & 902,5 \\
\hline Adalimumab & 40 mg/0.8 mL (1 ea) & 5411,3 & 1256,9 & $\begin{array}{l}1788 \\
9\end{array}$ & 2729,0 & $\begin{array}{l}4925 \\
6\end{array}$ & 796,4 & 2022,4 & 516,9 & 1080,5 \\
\hline $\begin{array}{l}\text { Adalimumab } \\
\text { (biosimilar) }\end{array}$ & 40 mg/0.8 mL (1 ea) & & 1256,9 & $\begin{array}{l}1788 \\
9\end{array}$ & & & & & & \\
\hline Baricitinib & 2 mg tablets (30 tablets) & 2240,4 & 1155,5 & $\begin{array}{l}1644, \\
4\end{array}$ & 920,9 & $\begin{array}{l}1662, \\
0\end{array}$ & & & 894,2 & 1869,0 \\
\hline $\begin{array}{l}\text { Certolizumabe } \\
\text { pegol }\end{array}$ & $200 \mathrm{mg}$ in $1 \mathrm{~mL}$, injection, kit & 9054,7 & 1164,4 & $\begin{array}{l}1657, \\
1\end{array}$ & 691,3 & $\begin{array}{l}1247 \\
7\end{array}$ & 703,5 & 1786,7 & 1059,4 & 2214,4 \\
\hline Etanercept & $\begin{array}{l}50 \mathrm{mg} / \mathrm{mL}(0.98 \mathrm{~mL}, 1 \mathrm{~mL}) \text {, Solution } \\
\text { Prefilled Syringe, Subcutaneous }\end{array}$ & 5411,2 & 848,7 & $\begin{array}{l}1207 \\
9\end{array}$ & 1255,1 & $\begin{array}{l}2265 \\
3\end{array}$ & 831,2 & 2110,8 & 1188,1 & 2483,4 \\
\hline $\begin{array}{l}\text { Etanercept } \\
\text { (biosimilar) }\end{array}$ & $\begin{array}{l}50 \mathrm{mg} / \mathrm{mL}(0.98 \mathrm{~mL}, 1 \mathrm{~mL}) \text {, Solution } \\
\text { Prefilled Syringe, Subcutaneous }\end{array}$ & & 848,7 & $\begin{array}{l}1207 \\
9\end{array}$ & 899,1 & $\begin{array}{l}1622 \\
7\end{array}$ & 415,6 & 1055,4 & & \\
\hline Golimumab & $50 \mathrm{mg} / 0.5 \mathrm{~mL}(0.5 \mathrm{~mL})$ & 5030,1 & 1359,6 & $\begin{array}{l}1934, \\
9\end{array}$ & 1316,6 & $\begin{array}{l}2376 \\
2\end{array}$ & 829,4 & 2106,3 & 1298,2 & 2713,4 \\
\hline Infliximab & 100 mg (1 ea) & $\begin{array}{l}1228 \\
70\end{array}$ & 687,0 & 977,8 & 1365,5 & $\begin{array}{l}2464 \\
7\end{array}$ & 390,2 & 990,9 & 713,1 & 1490,4 \\
\hline $\begin{array}{l}\text { Infliximab } \\
\text { (biosimilar) }\end{array}$ & 100 mg (1 ea) & 997,4 & 568,8 & 809,5 & 862,8 & $\begin{array}{l}1557, \\
3\end{array}$ & & & 400,4 & 836,8 \\
\hline Rituximab & 10 mg/mL (10 mL) & 1998,7 & 633,5 & 901,6 & 673,9 & $\begin{array}{l}1216 \\
3\end{array}$ & 451,9 & 1147,6 & 865,9 & 1809,9 \\
\hline $\begin{array}{l}\text { Rituximab } \\
\text { (biosimilar) }\end{array}$ & 10 mg/mL (10 mL) & & 546,5 & 777,8 & 404,9 & 730,7 & & & & \\
\hline Tocilizumab & $\begin{array}{l}20 \mathrm{mg} / 4 \mathrm{~mL}(4 \mathrm{~mL}), \text { Solution, } \\
\text { Intravenous }\end{array}$ & 476,9 & 215,3 & 306,3 & 165,8 & 299,3 & 97,2 & 246,9 & 192,6 & 402,6 \\
\hline Tofacitinib & 5 mg tablets (60 tablets) & 4687,3 & 1020,5 & $\begin{array}{l}1452 \\
4\end{array}$ & 1893,2 & $\begin{array}{l}3417, \\
1\end{array}$ & 810,2 & 2057,5 & 940,3 & 1965,3 \\
\hline
\end{tabular}


Table 2 Innovative and biosimilar drugs used to treat rheumatoid arthritis (RA), approved from 1998 to 2019, in the countries analyzed

\begin{tabular}{|c|c|c|}
\hline Drugs & Registration year & Country \\
\hline \multirow[t]{5}{*}{ Abatacept } & 2005 & US \\
\hline & 2007 & Brazil \\
\hline & 2012 & Spain \\
\hline & 2016 & Mexico \\
\hline & 2018 & Colombia \\
\hline \multirow[t]{4}{*}{ Adalimumab } & 2002 & US \\
\hline & 2003 & Brazil/Colombia \\
\hline & 2010 & Mexico \\
\hline & 2018 & Spain \\
\hline Adalimumab & 2018 & Spain \\
\hline \multirow[t]{2}{*}{ Biosimilar } & 2019 & Brazil/Colombia \\
\hline & 2015 & US \\
\hline \multirow[t]{3}{*}{ Baricitinib } & 2017 & Spain/Mexico \\
\hline & 2018 & US/Brazil \\
\hline & 2019 & Colombia \\
\hline \multirow[t]{4}{*}{ Certolizumabe pegol } & 2009 & US \\
\hline & 2011 & Brazil \\
\hline & 2016 & Colombia \\
\hline & 2017 & Spain/Mexico \\
\hline \multirow[t]{5}{*}{ Etanercept } & 1999 & Mexico \\
\hline & 2002 & US \\
\hline & 2003 & Brazil \\
\hline & 2006 & Spain \\
\hline & 2007 & Colombia \\
\hline \multirow[t]{4}{*}{ Etanercept biosimilar } & 2006 & Colombia \\
\hline & 2013 & Brazil/Mexico \\
\hline & 2016 & US \\
\hline & 2017 & Spain \\
\hline \multirow[t]{4}{*}{ Golimumab } & 2009 & US \\
\hline & 2011 & Brazil/Colombia \\
\hline & 2013 & Spain \\
\hline & 2014 & Mexico \\
\hline \multirow[t]{5}{*}{ Infliximab } & 1999 & Spain \\
\hline & 2000 & Colombia \\
\hline & 2001 & US \\
\hline & 2007 & Brazil \\
\hline & 2016 & Mexico \\
\hline Infliximab & 2014 & Spain/Mexico \\
\hline \multirow[t]{3}{*}{ Biosimilar } & 2013 & US \\
\hline & 2015 & Brazil \\
\hline & 2017 & Colombia \\
\hline \multirow[t]{2}{*}{ Rituximab } & 1998 & Brazil/Spain \\
\hline & 1999 & Colombia \\
\hline
\end{tabular}


Table 2 Innovative and biosimilar drugs used to treat rheumatoid arthritis (RA), approved from 1998 to 2019, in the countries analyzed (Continued)

\begin{tabular}{|c|c|c|}
\hline Drugs & Registration year & Country \\
\hline & 2006 & US \\
\hline & 2017 & Mexico \\
\hline Rituximab & 2017 & Spain/Mexico \\
\hline Biosimilar & 2019 & Brazil \\
\hline \multirow[t]{4}{*}{ Tocilizumab } & 2009 & Brazil/Mexico \\
\hline & 2010 & US \\
\hline & 2014 & Spain \\
\hline & 2015 & Colombia \\
\hline \multirow[t]{4}{*}{ Tofacitinib } & 2012 & US \\
\hline & 2013 & Mexico \\
\hline & 2014 & Brazil \\
\hline & 2018 & Colombia/Spain \\
\hline
\end{tabular}

country. Spain's price behavior seems intermediate when compared to the three LA countries. Brazil has the highest LA prices, followed by Mexico and Colombia, which have the lowest prices. When comparing US prices to Spanish prices in dollars, Spain has lower priced drugs.

For biosimilars, adalimumab is marketed only in Spain and has the same value as the original drug (US\$ 1256.9). The biosimilar etanercept has the same price as its original in Spain (US\$ 848.7) but is cheaper in Brazil and Colombia than the innovative drug (by 28.4 and $50 \%$, respectively). This biosimilar is, in turn, more expensive in both LA countries than in Spain. Infliximab is the only biosimilar of this class marketed in the US and has a difference of minus $18.8 \%$ from the value of the original product. Spain, Brazil and Mexico also have lower prices for this biosimilar $(17.2$; 36.8 ; and $43.9 \%$, respectively) than that of the innovative drug. Only Spain and Brazil trade the biosimilar rituximab, with prices up to approximately $40 \%$ cheaper than that of the original.

Prices were also correlated between countries, based on the PPP, when considering that the purchasing capacity changes compared to prices previously analyzed. Still under this interpretation, the US, which exhibited higher prices for biological drugs for the treatment of RA, maintains the highest PPP values, all higher than those of Spain and the LA countries, except for infliximab in Brazil and Mexico. The PPP for Spain is lower than that of the Latin American countries, except for adalimumab in Mexico, tocilizumab in Brazil and Colombia, biosimilar rituximab in Brazil and biosimilar etanercept in Colombia. The PPP values of Brazil are similar to those of Mexico, considering the absolute and relative number of medicines in each of these countries. Colombia's PPP values are lower than in Mexico and Brazil. The three LA countries have PPP values higher than those of Spain and lower than US drug prices.

\section{Discussion}

The main objective of this study was to analyze the evolution of the prices of biosimilar medicines in three LA countries, Spain and the US. Prices between countries were also compared on the basis of the PPP, which links drug values to differences in purchasing power levels. Our study points to a much lower affordability for the citizens of LA countries (as their prices, corrected by the PPP, were higher than in Spain, a wealthier country). This trend of the acquisition effort is not repeated in the United States, which has the highest PPP among the 5 countries. Putrik and collaborators [29] investigated the availability, accessibility and acceptability for synthetic and biological drugs in European countries, relating them to the socioeconomic status, well-being and health status of patients with RA. The prices of biological drugs for RA differed by up to 7.3 and 1.3 times, respectively, after adjusting for the PPP, between countries.

The findings of this paper should be carefully interpreted. For the price analysis of medicines, international comparisons should be cautious, as wholesale prices may produce misleading information [30]. Biological agents are only one drug class among many existing in the analyzed countries. We tried to compare the prices of drugs that coincided with each other in presentation, concentration, formulation, and manufacturer, but the periods in which they were available on the market are different. An ideal price analysis would control all these features. Sales data on these inputs would be important. The use of official databases, rather observing their structure, with information gaps that limit the progress of evaluations from these data, should be evaluated. There is a loss in the comparison between the PPP of the LA countries given the heterogeneity of the markets and inaccuracy in the data depicted. 
In addition to the great potential of the data available for health services, there is the scarcity of studies of this type and the complexity of exploring background information with so many particularities and differences.

Recent registration approvals, nonmarketing of the product or even the absence of distributors may be behind the absence of a drug in the market. These trends, registration approval characteristics, and the marketing itself provide important information for prescribers, patients, and the industry [31]. None of the drugs analyzed appear in the Mexican government's price comparison [32]. In Mexico, biosimilar approvals were found prior to those of the original products, somewhat illustrating the lack of clarity of the database [16]. Marketing approval for unregistered but sale-authorized biological agents in the European Union, the US, Canada, and Australia can be obtained in the respective countries [28]. Differences in legislation and database updating or completion may explain the different approval dates of biologics as approved biosimilars before their originals. In Colombia, Bernal-Camargo and collaborators [13] point to problems in the classification of Invimaregistered biosimilars, which, due to legal, information, availability and access barriers, make informed consumption difficult for the population.

Some biosimilar products, although approved for the US market, are not sold. These are licensing agreements with the original manufacturer that would allow the biosimilar to be launched later, up to 5 litigations, such as one of etanercept's biosimilars [33].

The high prices for medicines in the American market are not new. Mexico and Colombia may have lower prices than those in Brazil due to differences in input costs, tariff barriers, taxes, market power, industry regulation, healthcare systems or consumer preferences [34].

The economic impact of biosimilars on sanitary systems can be achieved through direct savings associated with lower prices. By competing with the original products, they eventually bring down the price of biological medicines [35]. According to Zozaya, and Gonzalez [11], the price difference between a biosimilar and its original ranges from 6 to 37\% in Europe. In addition, discounts on purchases often apply. In Spain, where the price of reference biologicals should equal the lowest price of their biosimilar counterparts, average discounts are $20 \%$ $[6,35]$.

\section{Conclusions}

The study compared biosimilar and biological drug prices and registration times for RA. Biosimilar market penetration of these RA drugs differs greatly from country to country, varying even within the commercialized therapeutic classes. The use of biosimilars may increase the viability of treatment of many patients in health care systems in emerging countries, where potential cost savings are highly valued.

The PPP strategy ensured a better understanding of access to biological products for RA. The economic effort of the United States and Spain is much less than that of these LA countries. Although the price of some of these drugs is lower in LA countries, the effort to obtain them is much higher and the differences noted are greater when converted into PPP units. Tracking the prices of these drugs as patents are lost can be a way to avoid monopolies. One step has already been taken regarding health regulation; other larger ones should take place regarding pricing and agreements with the pharmaceutical industry.

\section{Acknowledgements \\ Carolina Foundation and Tordesillas Group for GBGM three months scholarship.}

\section{Conflict of interest}

none, stated by the authors.

\section{Declaration}

The opinions expressed in this manuscript are those of the authors and do not necessarily reflect HER's criteria or policy.

\section{Authors' contributions}

GBGM had substantial contributions to the conception and design of the work, analysis and interpretation of data, draft the paper and revised it. FA had substantial contributions to the conception and design of the work, interpretation of data and revision of the final manuscript. CMMV had contribute with the analysis and interpretation of data and revision of the final manuscript. PR had contribute with the analysis and interpretation of data and revision of the final manuscript.

We agreed both to be personally accountable for the author's own contributions and to ensure that questions related to the accuracy or integrity of any part of the work, even ones in which the author was not personally involved, are appropriately investigated, resolved, and the resolution documented in the literature.

All authors read and approved the final manuscript as they have approved the submitted version.

\section{Funding}

GBGM received a three-month fellowship for a postdoctoral office in Logroño (Spain) during the preparation of this study by the Carolina Foundation in collaboration with the Tordesillas Group.

Availability of data and materials

All data generated or analyzed during this study are included in this published article.

Ethics approval and consent to participate

Not applicable.

Consent for publication

Not applicable.

\section{Competing interests}

None.

\section{Author details}

${ }^{1}$ Department of Health and Society, Community Health Institute, Fluminense Federal University, Rua: Marquês do Paraná, 303, $3^{\circ}$ floor, annex building, Niterói, RJ CEP: 24033-900, Brazil. Department of Economy and Company, Economy Faculty, University of La Rioja, Calle la Cigüeña, 60, 26006 Logroño, La Rioja, Spain. ${ }^{3}$ Department of Health Policy, Planning and Management, Health Medicine Institute, Rio de Janeiro Estadual University, Rua São 
Francisco Xavier 524 - Maracanã, Bloco D, $7^{\circ}$ floor, Rio de Janeiro, RJ 20550-013, Brazil. Department of Economy and Company, Economy Faculty, University of La Rioja, Calle la Cigüeña, 60, 26006 Logroño, La Rioja, Spain.

Received: 21 May 2020 Accepted: 9 February 2021

Published online: 25 February 2021

\section{References}

1. Burgos-Vargas R, Catoggio LJ, Galarza-Maldonado C, Ostojich K, Cardiel MH. Current therapies in rheumatoid arthritis: a Latin American perspective. Reumatol Clínica English Ed. 2013;9(2):106-12. https://doi.org/10.1016/j. reumae.2013.01.007.

2. Brasil. Ministério da Saúde. Coordenação de Gestão de Protocolos Clínicos e Diretrizes Terapêuticas. Protocolo Clínico e Diretrizes Terapêuticas da Artrite Reumatoide . Brasilia; 2020 [access 2020 Nov 19]. p. 171. Available from: http://conitec.gov.br/images/Consultas/Relatorios/2020/Relatrio_Artrite_ Reumatoide_CP_21_2020.pdf

3. Zozaya N, Pérez-Camarero S, Martínez-Galdeano L. La regulación y financiación de los medicamentos biosimilares en la OCDE. Madrid: Weber. Org.Es.; 2017. Report No.: 01/2017. Available from: http://weber.org.es/wpcontent/uploads/2018/04/La_Regulacion_y_financiacion_de_los-biosimila res_en_la-OCDE_weber.pdf

4. Castañeda-Hernández G, Szekanecz Z, Mysler E, Azevedo VF, Guzman R, Gutierrez M, et al. Biopharmaceuticals for rheumatic diseases in Latin America, Europe, Russia, and India: innovators, biosimilars, and intended copies. Jt Bone Spine. 2014;81(6):471-7 Available from: https://linkinghub. elsevier.com/retrieve/pii/S1297319X14000992.

5. Levenhagen K, Davies C, Perdomo M, Ryans K, Gilchrist L. United Rheumatology Clinical Practice Guideline. Vol. 97; 2019.

6. Quintiles IMS Institute. The Impact of Biosimilar Competition in Europe 2017. p. 33. Available from: https://www.medicinesforeurope.com/wpcontent/uploads/2017/05/IMS-Biosimilar-2017_V9.pdf

7. Agência Nacional de Vigilância Sanitária (Anvisa). Anuário Estatístico do Mercado Farmacêutico . 2018 [access 2019 Nov 1]. p. 28. Available from: http://portal.anvisa.gov.br/documents/374947/3413536/Anuário+Estatístico+ do+Mercado+Farmacêutico+-+2017/3179a522-1af4-4b4c-8014-cc25a90fb5a 7

8. México: Instituto Mexicano del Seguro Social. Diagnóstico y Tratamiento de Artritis Reumatoide del Adulto . Delegación Cuauhtémoc; 2010 [access 2019 Nov 1]. p. 97. Available from: http://www.imss.gob.mx/sites/all/statics/guia sclinicas/195GRR.pdf

9. CenterWatch. FDA Approved Drugs - Listings in Rheumatology . 2019 [access 2019 Nov 1]. p. 2. Available from: https://www.centerwatch.com/ directories/1067-fda-approved-drugs/topic/110-rheumatology

10. Brasil. Ministério da Saúde. Secretaria de Atençao a Saúde. Portaria N ${ }^{0} 996$ de 30 Dde Setembro de 2015 . 2015 [access 2019 Nov 8]. Available from: http://bvsms.saude.gov.br/bvs/saudelegis/sas/2015/prt0996_30_09_2015. html

11. Zozoya N, González A. El irresistible ascenso del mercado de los biosimilares. Gestión Clínica y Sanit . 2018;(1):59-63. Available from: http:// weber.org.es/wp-content/uploads/2018/10/Artículo_el-irresistible-acceso-delos-biosimilares.pd

12. Mysler $E$, Scheinberg M. Biosimilars in rheumatology: a view from Latin America. Clin Rheumatol. 2012;31(9):1279-80.

13. Bernal-Camargo DR, Gaitán-Bohórquez JC, León-Robayo Él. Biosimilar medicines in Colombia: an approach from the informed consumption. Rev Ciencias la Salud. 2018;16(2):311-39 Available from: https://revistas.urosario. edu.co/index.php/revsalud/article/view/6772.

14. Garcia R, Araujo DV. The regulation of biosimilars in Latin America. Curr Rheumatol Rep. 2016;18(3):1-8 Available from: https://pubmed.ncbi.nlm.nih. gov/26951254/.

15. Gomes EBP, Rosseto R, Pinheiro L, Hasenclever L, Paranhos J. Desenvolvimento de biossimilares no Brasil. Fronteiras. 2016;5(1):31-42.

16. Comisión Federal para la Protección contra Riesgos Sanitarios (Cofepris). Listados de Registros Sanitarios de Medicamentos. Governo do México. 2019 [access 2019 Nov 1]. Available from: https://www.gob.mx/cofepris/ documentos/registros-sanitarios-medicamentos

17. Agência Nacional de Vigilância Sanitária (Anvisa). Consulta ao registro de medicamentos . 2019 [access 2019 Nov 1]. Available from: http://portal.a nvisa.gov.br/consulta-produtos-registrados
18. Instituto Nacional de Vigilância de Medicamentos y Alimentos (Invima). Consulta Datos de Productos. Registro de Medicamentos. 2019 [access 2019 Nov 1]. Available from: https://www.invima.gov.co/consultas-registrosy-documentos-asociados

19. Consejo General de Colegios Oficiales de Farmacéuticos (España). Consulta precios medicamentos España. 2019.

20. Agência Nacional de Vigilância Sanitária (Anvisa). Consulta ao preço de medicamentos . 2019 [access 2019 Nov 1]. Available from: http://antigo.a nvisa.gov.br/consulta-lista-de-preco-de-medicamento

21. Drugs.com. Buscador de preços de medicamentos. Drugs.com. 2019 [access 2019 Nov 1]. Available from: https://www.drugs.com/

22. Ministerio de Salud y Protección Social. Colombia. Base de datos de medicamentos con precio regulado o con precio de referencia . 2018. 2019 [access 2019 Aug 1]. Available from: https://actuarsalud.com/base-de-datosde-medicamentos-con-precio-regulado-o-con-precio-de-referencia/

23. Ministerio de la Salud y Proteccion Social. Colombia. Regulación de precios de medicamentos. Ministerio de la Salud y Proteccion Social. 2019 [access 2019 Nov 1]. Available from: https://www.minsalud.gov.co/salud/MT/Pagina s/medicamentos-regulacion-precios.aspx

24. San Pablo Farmacia. Buscador de preços de medicamentos. Mexico (DF). 2019 [access 2019 Nov 1]. Available from: https://www.farmaciasanpablo. com.mx/?gclid=Cj0KCQiAtf tBRDtARIsAlbAKe1 v-aDMSM4JYWVpQx5VrkCyfphP8cN3IGOQh22WC_qn77EdrcBvDoaAm8CEALw_wcB

25. Banco Central do Brasil. Conversor de moedas e câmbio . Banco Central do Brasil. 2019 [access 2019 Nov 1]. Available from: https://www.bcb.gov.br/ conversao

26. World Bank. PPP conversion factor, GDP . 2019 [access 2019 Nov 1]. Available from: https://data.worldbank.org/indicator/PA.NUS.PPP

27. Babu N. Salary Converter . 2019 [access 2019 Nov 1]. Available from: http:// salaryconverter.nigelb.me/

28. Comisión Federal para la Protección contra Riesgos Sanitarios (Cofepris) Registro sanitario de producto biológico cuyo ingrediente activo no está registrado en México . Cofepris. 2019 [access 2019 Nov 1]. Available from: https://www.gob.mx/tramites/ficha/registro-sanitario-de-producto-biologicocuyo-ingrediente-activo-no-esta-registrado-en-mexico/COFEPRIS4000

29. Putrik P, Ramiro S, Kvien TK, Sokka T, Pavlova M, Uhlig T, et al. Inequities in access to biologic and synthetic DMARDs across 46 European countries. Ann Rheum Dis. 2014;73(1):198-206.

30. Araujo DV. Preço de medicamentos na América Latina : desafios para definição de preço de referência na região. Estudo de caso : Mercosul. J Bras Econ da Saúde. 2015;55(21):86-90 Available from: http://files.bvs.br/ upload/S/2175-2095/2015/v7n2/a4933.pdf.

31. MarketResearch.com. The Growing Pharmaceuticals Market: Expert Forecasts and Analysis . Rockville, MD (US). 2019 [access 1 Nov 2019]. Available from: https://blog.marketresearch.com/the-growing-pharmaceuticals-marketexpert-forecasts-and-analysis

32. Mexico. Secretaria de Economia. Precios de medicamentos de patente. Ciudad de México, DF: Secretaria de Economia; 2017 [access 2019 Jun 25]. p. 9. Available from: https://datos.gob.mx/busca/dataset/precios-de-medica mentos-de-patente-de-se

33. Biosimilars Review \& Report. Biosimilars, Biologics, FDA Policy and Approvals, Clinical Trials, and Specialty Pharmacy . 2019 [access 2019 Sept 20]. Available from: https://biosimilarsrr.com/biosimilars-reviews-reports/

34. Álvarez R, Alvarez R, González A. SDT 462 Análisis Comparativo de Precios de Medicamentos en América Latina Medicamentos en América Latina. 2018. Available from: http://repositorio.uchile.cl/bitstream/handle/2250/1 51440/Analisis-comparativo.pdf?sequence=1\&isAllowed $=y$

35. Rodrigo J. Medicamentos biosimilares: una oportunidad para el sistema nacional de salud. Papeles de Economía Española 2019. Available from: https://www.biosim.es/wp-content/uploads/2019/06/160art20.pdf

\section{Publisher's Note}

Springer Nature remains neutral with regard to jurisdictional claims in published maps and institutional affiliations. 